\title{
TEACHERS BEHAVIOR TOWARD DIGITAL EDUCATION
}

\author{
Siti Nur Aqila Anuar ${ }^{1}$ \\ School of Maritime Business and Management, \\ Universiti Malaysia Terengganu (UMT), Malaysia \\ (Email: sitinuraqilaanuar@gmail.com) \\ Noor Fadhiha Mokhtar ${ }^{2}$ \\ School of Maritime Business and Management, \\ Universiti Malaysia Terengganu (UMT), Malaysia \\ (Email: noorfadhiha@umt.edu.my) \\ Kalsitinoor Set $^{3}$ \\ School of Maritime Business and Management, \\ Universiti Malaysia Terengganu (UMT),), Malaysia \\ (Email: kalsitinoor@umt.edu.my)
}

Accepted date: $24-02-2019$

Published date: 09-07-2019

To cite this document: Anuar, S. N. A., Mokhtar, N. F., \& Set, K. (2019). Teacher Behavior toward Digital Education. Journal of Information System and Technology Management, 4(13), 32-47.

DOI: $10.35631 / J I S T M .413004$

\begin{abstract}
The education system in Malaysia has increased with the use of computers as a teaching tool. Technological amenities such as Internet technology are created as a successful teaching and learning branch. Terms of Digital education is one of the educational transformation efforts undertaken by Ministry of Education Malaysia (MOE) under the Malaysian Education Development Plan (PPPM) 2013-2025 which focus more on digital and Internet materials at schools and known as a 21st Century Learning (PAK-21). Although the $M O E$ introduced this digital education system for the convenience of teachers, the teacher's desire to use computers was limited, and there were some constraints faced by teachers in implementing digital classroom teaching. Computer literacy skills became a significant constraint among teachers. Incomplete teachers handle computers; have low confidence in using computers in the school and vice versa (Gilakjani, Mei \& Ismail, 2013). This study aims to analyze the intention of Digital Education behavior among Malaysian school teachers and to explore individual skills as an advanced component of the extended Theory of Planned Behavior (TPB). Also, this study aims to examine the role of Attitude, Subjective Normative and Perceived Behavioral as intermediaries on the relationship between individual skills and intentions to use the Internet among school teachers in Malaysia and to develop an extended TPB model including Individual Skills. To achieve this objective, this study examines the behavioural intention of secondary school teachers in Peninsular Malaysia towards this digital education based on the framework of the TPB. A structured questionnaire has been provided to 91 teachers based from table Green (1991) as the samle size for this research and the teachers scome from government secondary schools in Malaysia and to obtain information about the characteristics and performance of their management. A descriptive and inferential analysis was conducted using the Smart PLS 3.0 statistics package. This study provides strong empirical evidence to demonstrate that to increase the use of digital education among teachers in Malaysia there is a need to improve the interest and skills to be exposed to teachers and to use this digital education well and not
\end{abstract}


misused. This can be achieved through the development of a policy and effective government creation and providing greater awareness of digital education programs is easier to use than traditional learning methods.

Keywords: Internet, Digital Education, Theory of Planned Behaviour, Individual Skills

\section{Introduction}

The Internet is an example of the most extensive network connecting millions of computers scattered all over the world and not bound to one organisation (Deasy \& Firniawati, 2014). Abdullah \& Osman, (2010) have found that the National Education Policy in line with Malaysia's vision to become a developed nation by the year 2020 in front of the PAK-21 and is very much related to the use of the Internet. The Internet is an essential item for the success of PAK-21 where any digital education method introduced by the MOE will not work correctly with the Internet channel. Jamaluddin (2010), think that teachers are still unsure about the effectiveness of digital use in Teaching and Learning Process (PDP). There are also teachers who are even less skilled in the use of digital materials. Lubis, (2017) says that the government has supplied thousands of computers to schools nationwide. This is as a government effort to improve teaching professionalism. The government intends to ensure that all teachers in primary and secondary schools use computer-assisted digital materials in the PDP process as learning aids (ABM). According to Arsyad, (2011) MOE has introduced digital systems as ABM in all subjects in schools. This means that a positive transformation in education has been aided with digital support over the last few years. For example, printed textbooks have transformed into a digital-based source of e-books and cyberspace as the Internet is used as a continuing learning tool. Meanwhile, teachers applying the digitalassisted use of computers in PDP in the classroom have the potential to provide creative and innovative teaching.

The government recognises that the use of the Internet in education brings many benefits, but the use of computers among teachers is quite limited. The development of digital learning in Malaysia is still new when compared to western countries and Singapore (Buntat, 2010). This growth also has an impact on the people in Malaysia, especially in the country's education system. To improve the quality of education, various initiatives have been implemented to create a more creative and effective teaching and learning environment that will eventually produce a sustainable backdrop of knowledge and skills (Samian \& Awang, 2017). The handling of software 'hardware' and 'software' creates teachers to face many problems and do not want to use them in class (Shanmugan \& Balakrishnan, 2018).In. As a result, computer literacy skills are a significant obstacle among teachers and teachers who are inadequate to operate computers and have low confidence in using computers at school and vice versa. This study will show the level of computer usage in teaching and the intention of digital education behaviour among teachers. It is therefore important to analyse the behaviour of school teachers in Malaysia and to identify the factors that influence them. The existing theory of Planned Behaviour (TPB) with has combined to the Individual Skills. Therefore, this study can help the MOE to devise strategies to support and motivate academics to use the Internet digitally by making more changes in school teaching and learning processes to become eschools.

\section{Literature Review}

This paper has investigated the intention of Malaysian school teachers toward digital education. The use of digital education has expanded either in the industrial or educational 
sectors around the world. In the industrial field, the use of digital in training continues to increase (Mohamed, 2011). Impact of the digital in education; content, technology and services identified as three key points to the success of the digital knowledge coupled with the growing Internet and multimedia technology now are the cornerstone of the ever increasing use of digital education worldwide. In the education sector, digital education has grown since 2006 with an estimated 3.5 million students taking part in online learning at the United States of America (Sloan Consortium). More institutions of higher education offering online courses and programs have overgrown (Hebert, 2007). In Malaysia, it is focused on distance learning and online learning, which is mostly offered at university and private colleges that have partnerships with overseas universities where fees are high and expensive. In Singapore, digital education has grown in the form of an on-the-go repository idea that assists the education industry in the country to create new Digital Education courses that enable immediate editing work and online (Buntat, 2010). The hypothesis of the past research relationship among variable is determine whether all of independent variable directly or indirectly influence on behavioural intention which is the Internet usage.

\section{Digital Education}

Digital learning often fluctuates in line with the latest technology today. This is always often misinterpreted in educational promotion ads. In general, digital education is the teaching and learning that uses the electronic network Local Area Network (LAN), Wide Area Network (WAN) or internet to deliver content, interaction or facilitating. Internet, Intranet, satellite, audio/video tape, interactive TV and CD- ROM are some of the electronic media intended in this category (Buntat, 2010). Teaching can be conducted simultaneously (at the same time) or 'Asynchronously' (at different times). Teaching and learning materials can be conveyed through this media that have multimedia features such as text, graphics, animation, simulation, audio and video. It should also provide facilities for 'discussion groups' and enable guidance on online 'online' (Buntat, 2010).

\section{Extended Theory of Planned Behaviour}

This section will focus on the antecedents and the consequences on the extended TPB model. The antecedents and outcomes in the proposed research model in this study are Individual Skill.

\section{Individual Skills (IS)}

Moreover, as teachers with less experience tend to show a higher emotional quality toward students than teachers with more experience tend to do reported in National Institute of career development (NICD, 2006) such emotional condition may be necessary for activating attention toward a particular student who exhibits problems in his or her performance (Saric, 2015). Previous studies that have investigated the influence of class size, teachers' teaching experience, and the number of teaching assistants on class-level instruction have shown mixed findings. For instance, most studies on the role of teachers' teaching experience in the quality of instruction have not found any associations (Nurmi et al., 2013).

The process of teaching and learning is a process that involves the interaction of teachers with students. The effectiveness of teachers' education is dependent on how teachers can adapt and understand the problem of student learning. There are various aspects that influence the quality of teacher teaching (Azizi \& Rosnani, 2015). The methods used by teachers in implementing the teaching process and teacher personality. These aspects must be identified and understood. Among these issues is the teaching experience of a teacher, the 
subject taught by the teacher and the training that the teacher has attended (Yahaya et al., 2006).

Holwerda, (2018) claimed that skills has a positive relationship with the intention while Bali, (2014) stated that finding more positive attitudes toward the behaviour and higher intentions to produce such behaviour. However, Fanning \& Ricks, (2017) found that individual skills significant factors with subjective norms and individual's skills are positive related with behaviour to usage the computer (Igbaria et al., 2015). As a result, we have come out with the following hypothesis:

H1: Individual skills are positively significant related with the intention to use among school teachers.

$\mathrm{H} 2$ : Individual skills are positively significant related to an attitude among schools teachers H3: Individual skills are positively significant related to subjective norms among schools teachers.

H4: Individual skills are positively related to perceive behavioural among school teachers.

\section{Theory of Planned Behaviour}

The theory of planned behaviour (TPB) model developed by Ajzen (1991) is used as one of the most recognised testing instruments for measuring the cognitive factors of consumers. TPB proposes that behaviour is determined by the combination of an individual's intentions to engage in a particular behaviour. According to the TPB, human behaviour is guided by three kinds of beliefs (Ajzen 1991).1) Behavioural beliefs it's about the likely outcomes of the behaviour and the evaluations of these outcomes. These beliefs produce a favourable or unfavourable attitude toward the behaviour. 2) Normative beliefs refer to the perceived behavioural expectations of such important referent individuals or groups as the person's spouse, family, friends, and teacher, doctor, supervisor, and co-workers, depending on the population and behaviour studied. These beliefs result in perceived social pressure or subjective norm and 3) Control believes it's about the presence of factors that may facilitate performance of the behaviour and the perceived power of these factors. These beliefs indicate whether the person feels in control of the action in question and they give rise to perceived behavioural control. Further, TPB has emerged as one of the most influential and popular conceptual frameworks for the study of human action in Figure 1.

\section{Attitude (ATT)}

The concept that attitudes towards teams are a collective identity has been used for conventional marketing methods such as segmentation where the focus is on the similarity of consumers (Sumida et al., 2014). According to Soares et al., (2017) attitudes are hypothetical constructs that refer to "a psychological tendency that is expressed by a particular entity with some degree of favour or disfavour". The computer has stirred deep and keen interest in education over the past decade. In many developed countries, teachers are already using computers in the classrooms. Developing countries such as Malaysia are trying to introduce networks in schools on a national scale. This is necessary because information technology tools such as the computer have made a significant impact in developed societies and will soon be widely used by many segments of society worldwide (Abbas, 1995). However, research has shown that one factor in the successful implementation of computers in educational institutions is user acceptance and user acceptance is believed to be influenced by user attitudes (Koohong, 1989). It is expected that once user attitudes are identified, steps may be taken to change these attitudes, if necessary. Teachers' attitudes have also been found to be the key to the successful implementation of computers in schools (Hunter \& Deleeew, 
1986; Stevens 1980). A study by Kabir et al., (2017) found that attitude will influence their behavioral intention and attitude was reported to be the most important factor that predicted the intention (Brouwer et al., 2009). Hence, our next hypothesis is follows:

H5: Attitude is positively significant related to intention to use the Internet among school teachers.

\section{Subjective Norms (SN)}

Yarmen et al., (2016) found that subjective norm can be defined as someone's perception of the pressure of his/her relatively talented people to perform or not to perform behavior. The researchers also conclude that the strength of the relationship between subjective norm and intention to share knowledge is hugely influenced by facilitating favorable organizational climate (Rahman et. al, 2016). The TPB holds that subjective norm is a function of beliefs. Beliefs that underlie the subjective norm are called normative understanding. Thus, if a person believes that the most critical referents think that behavior should be performed, then the subjective norm should influence the intention of the individual to perform the behaviour in question(Bidin, Shamsudin \& Sharif, 2010). The referents here refer to a group of people who are close to the individual, for instance, family, peers, spouse, close friends, teachers, and many people who are considered necessary. Organizational studies have found subjective norm to be an essential determinant of behavioural intention to use information technology (Hartwick \& Barki, 1994; Moore \& Benbasat, 1993). Previous studies found that subjective norms have significantly towards intention (Chuchinprakarn, 2005) and the hypothesized is follows:

H6: Subjective Norms is positively significant related to intention to use the Internet among school teachers.

\section{Perceived Behavioral Control (PBC)}

If this belief is related to specific achievements, such as one's belief in mastering computing skill well, then it is called perceived behavioral control (Reni \& Anggraini, 2016). Ajzen (1988) defines behavioral control as follows: "this factor refresh to the perceived ease or difficulty performing the behavior and it assume to reflect experience as well as anticipates impediment and obstacles", which means that these factors reflect the perceptions would be challenging or not perform an action and assumed a reflection of experience and anticipation of obstacles. This construct is affected by perceptions of access to necessary skills, resources, and opportunities to perform the behavior. If an individual does not have control over the circumstances, he/she may not have any or have less intention to achieve particular behavior (Bidin, Shamsudin \& Sharif, 2010). In behaviour intention research, perceived behavioural control has been found a significant determinant of usage intention as revealed by Mathieson (1991). In general, attitude toward the behavior and perceived behavioral control significantly explained variation in intention (Smith, 2018) and perceived behavioral control significantly relationships between beliefs and intention (Close et al., 2015). Hence, our final hypothesis is as follows:

H7: Perceived Behavioral Control is positively significant related to intention to use the Internet among school teachers. 


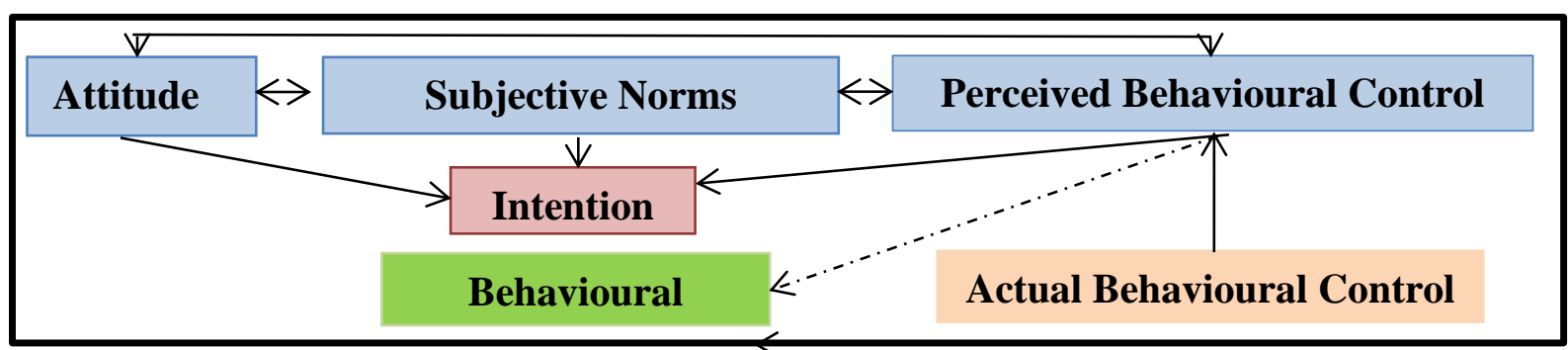

Source: (Ajzen, 2006)

Figure 1: Theory of Planned Behavior (TPB)

\section{Intention to Use (ITU)}

Intentions reflect a conscious plan or decision to enact the behaviour (Rhodes et al., 2013). The TPB also tries to predict in- entirely volitional behaviours by incorporating perceptions of control over the performance of the behaviour as an additional predictor and the structural effects of attitude, subjective norm, PBC, and intention were freed based on the tenets of the TPB (Ajzen, 1991). The TPB was developed to predict an individual's behavioural intentions toward a specific event (Ajzen, 1985, 1991). Behavioural intention represents an individual's readiness or willingness to behave in a certain way (Ajzen, 1985). TPB posits that the individual's behavioural intention is influenced directly by motivation factors in their decision-making processes (Kam et al., 2018). The more favourable attitudes and subjective norms combined with greater perceived behavioural control, the stronger the intention of environmentally- oriented behaviour (Ham et al., 2016).

\section{Development of Theoretical Framework}

Previous studies agreed upon the need for adding other variables in TPB to measure aspects of control associated with individual skills along with available resources and management support in Figure 2 (Buhmann et al., 2018). Ajzen and Fishbein (1980) proposed the theory of planned behaviours (TPB) to suggest that individual behavioural intention would be influenced by environmental pressure caused by norms.

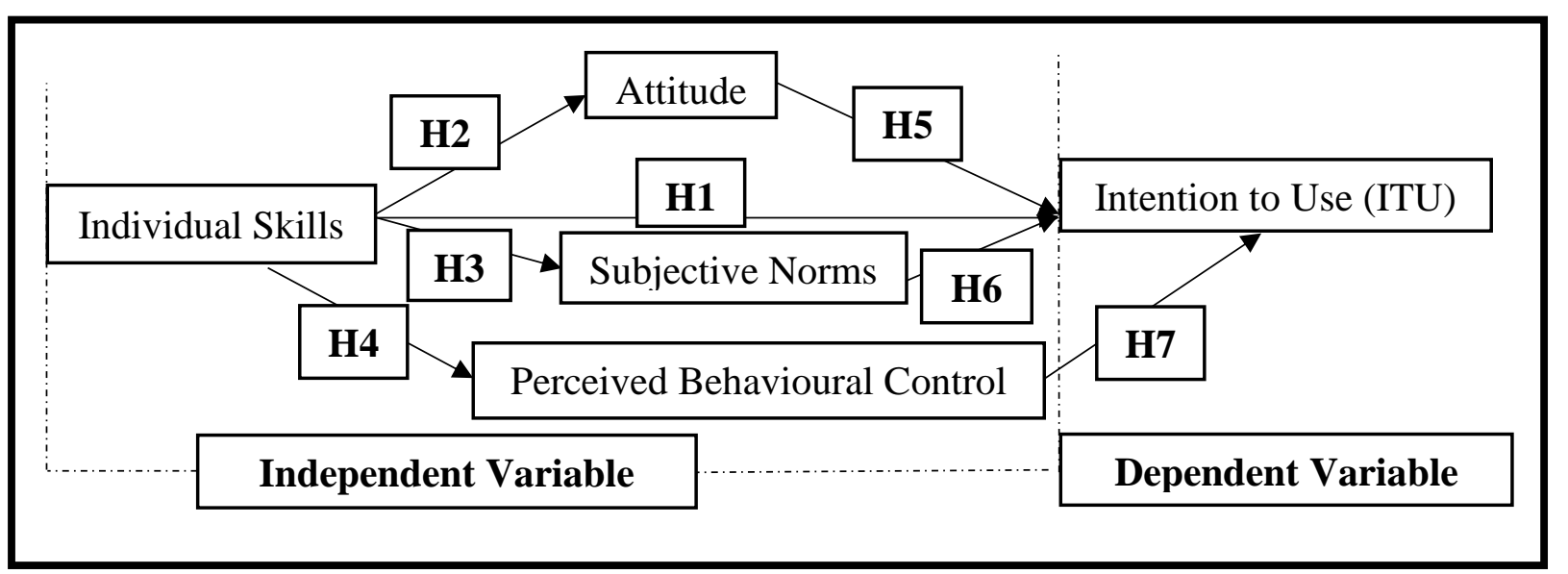

Figure 2: Research Model

Source: (Buhman et al., 2018)

\section{Research Methodology}

The unit of analysis of this study is at high school government only. The respondent of this study were the teachers that have intention to use digital education in classroom PDP for 
teachers day-to-day and convenience. According to the list from E-Operation from MOE on June 1, 2016 in Table 1, there are 181,978 teachers come from secondary school. E-Operation is the system, that MOE can know the number of teachers from the current mascot in Malaysia. E-Operation is one of the modules for School Management System (SPS), MOE under the Master's Management. This module is developed by the Information Management Division (BPM) supported by the School Management Division (BPSH), Human Resource Management Division (BPSM), and MOE Operations Sector (SOP) and it involves the management of data related to teachers and non-teachers involving several categories of users, for users (teachers and non-teachers) and system administrators MOE management at Division, State, District, and School level).

Table 1: Statistics of Teachers in Malaysia

\begin{tabular}{lc}
\hline \multicolumn{1}{c}{ Level } & Number Of Teachers \\
\hline Primary School & 239,850 \\
\hline Secondary School & 181,978 \\
\hline Total & 421,828 \\
\hline
\end{tabular}

Source: Malaysia Education Ministry 2017

Based on Green (1991) to test the predictors to the framework based on the theory adopted or improved, it will assume a medium effect size by (Cohen, 1988; Gefen et al., 2011). Table 2 is the Initial sample size requirements show the rations of the population and sample. Five predictors from the research framework which is Individual Skill, Attitude, Subjective Norms, Perceived Behavioural Control and Intention to use, it shows that the minimum sample size is 91 .

Table 2: Initial sample size requirements

\begin{tabular}{llll}
\hline Number of predictors & \multicolumn{2}{l}{ Effect Size } & \\
\hline 1 & Small & Medium & Large \\
\hline 2 & 390 & 53 & 24 \\
\hline 3 & 481 & 66 & 30 \\
\hline 4 & 547 & 76 & 35 \\
\hline 5 & 599 & 84 & 39 \\
\hline 6 & 645 & 91 & 42 \\
\hline 7 & 686 & 97 & 46 \\
\hline 8 & 726 & 102 & 48 \\
\hline 9 & 757 & 108 & 51 \\
\hline 10 & 788 & 113 & 54 \\
\hline 15 & 844 & 117 & 56 \\
\hline 20 & 952 & 138 & 67 \\
\hline 30 & 1066 & 156 & 77 \\
\hline 40 & 1247 & 187 & 94 \\
\hline 1 & 1407 & 213 & 110 \\
\hline
\end{tabular}

Source: (Green, 1991)

\section{Measurement of Variables}

All items used to measure the constructs in the theoretical framework were adopted and adapted from (Armitage \& Conner, 2001) that covers the items to measure IS, ATT, SN, PBC and ITU. To analyse data use PLS-SEM, previous study by (Cohen, 1988; Chin, 1998) using Table Green (1991) for accurate assessment. 


\section{Data Analysis and Findings}

The data were analysed using Smart PLS version 3.2.7 software that developed by Ringle et al (2015), which is a variance based on structural equation modelling (SEM). SEM is a technique to estimate causal relationship among variables. Following the two-stage analytical procedure, the measurement model is analysed first to assess the reliability and validity of the instrument and then hypotheses were tested through the structural model. The detail descriptions of both measurement model and structural model are summarised in the following sections. It is a suitable choice to present the analysis instead of using covariancebased SEM because this study intended to predict the relationship between the variables in the research model rather than reproducing the covariance matrix to achieve model fit (Hair et al., 2016). SEM is a technique to estimate causal relationship among variables. Following the two-stage analytical procedure, the measurement model is analysed first to assess the reliability and validity of the instrument and then hypotheses were tested through the structural model. The detail descriptions of both measurement model and structural model are summarised in the following sections.

\section{Measurement Model}

The first test is convergent validity which reflects whether a particular item measures a latent variables that it is supposed to be (Urbach \& Ahlemann, 2010). Hair et al. (2016) proposed that the loading and average variance explain (AVE) must exceed 0.5, and the composite reliability (CR) must reach 0.7 to ensure that convergent validity is established in the model. Thus, it can be confirmed that the measurement model showed the evidence of convergent validity. A measurement model has satisfactory internal CR each construct exceeds the threshold value of 0.7. Table 3 shows that the CR of each construct for this study ranges from 0.879 to 0.944 and this is above the recommended threshold value of 0.7 and show the loadings on each item also the AVE on each indicator and loadings on each item. Figure 3 show the loadings on each indicators and the $\mathrm{R}$ square. Table 3 and figure 3 describe the results of the measurement model.

Table 3: Measurement Model

\begin{tabular}{llrrr}
\hline Construct & Items & Loadings & CR & AVE \\
\hline Attitude & AT1 & 0.774 & 0.939 & 0.582 \\
\hline & AT2 & 0.741 & & \\
\cline { 2 - 3 } & AT3 & 0.734 & & \\
\cline { 2 - 3 } & AT4 & 0.793 & & \\
\cline { 2 - 3 } & AT5 & 0.782 & & \\
\cline { 2 - 3 } & AT6 & 0.739 & & \\
\cline { 2 - 3 } & AT7 & 0.812 & & \\
\cline { 2 - 3 } & AT8 & 0.742 & & \\
\cline { 2 - 3 } & AT9 & 0.786 & & \\
\cline { 2 - 3 } & AT10 & 0.744 & & \\
\cline { 2 - 3 } & AT11 & 0.742 & & \\
\hline & IS1 & 0.759 & 0.879 & 0.593 \\
\hline & IS2 & 0.782 & & \\
\hline & IS3 & 0.780 & & \\
\cline { 2 - 3 } & IS4 & 0.804 & & \\
\hline
\end{tabular}




\begin{tabular}{|c|c|c|c|c|}
\hline & IS5 & 0.723 & & \\
\hline \multirow[t]{9}{*}{ Intention to use } & IT1 & 0.833 & 0.936 & 0.621 \\
\hline & IT2 & 0.758 & & \\
\hline & IT3 & 0.809 & & \\
\hline & IT4 & 0.808 & & \\
\hline & IT5 & 0.848 & & \\
\hline & IT6 & 0.810 & & \\
\hline & IT7 & 0.758 & & \\
\hline & IT8 & 0.705 & & \\
\hline & IT9 & 0.753 & & \\
\hline \multirow[t]{9}{*}{ Perceived Behavioural } & PB1 & 0.760 & 0.944 & 0.654 \\
\hline & PB2 & 0.810 & & \\
\hline & PB3 & 0.820 & & \\
\hline & PB4 & 0.809 & & \\
\hline & PB5 & 0.841 & & \\
\hline & PB6 & 0.862 & & \\
\hline & PB7 & 0.782 & & \\
\hline & PB8 & 0.808 & & \\
\hline & PB9 & 0.780 & & \\
\hline \multirow[t]{11}{*}{ Subjective Norms } & SN1 & 0.708 & 0.937 & 0.674 \\
\hline & SN2 & 0.708 & & \\
\hline & SN3 & 0.790 & & \\
\hline & SN4 & 0.777 & & \\
\hline & SN5 & 0.796 & & \\
\hline & SN6 & 0.780 & & \\
\hline & SN7 & 0.721 & & \\
\hline & SN8 & 0.715 & & \\
\hline & SN9 & 0.799 & & \\
\hline & SN10 & 0.783 & & \\
\hline & SN11 & 0.750 & & \\
\hline
\end{tabular}




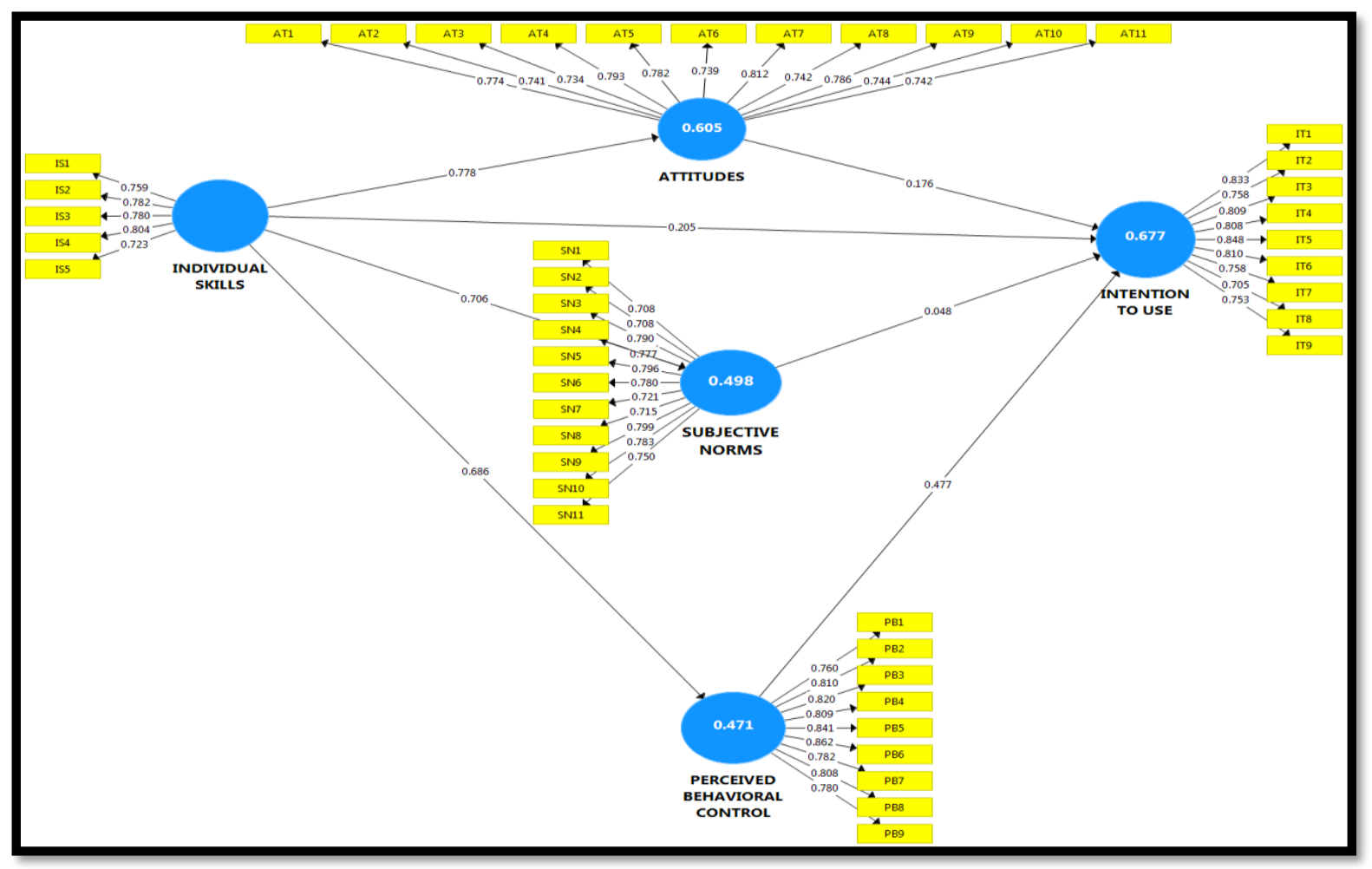

Figure 3: Measurement Model

Discriminant validity assesses the extent to which a concept and its indicators differ from another idea and its indicator also is measured by examining the correlation between the measures of the potential overlapping constructs (Fornell \& Larcker, 1981). According to Compeau \& Higgins, (2018) the average variance shared between each construct and its measure should be greater than the variation shared between the constructs and other constructs. Table 4 showed the results of discriminant validity, all the diagonal values (square root of AVE) are higher than off-diagonal values (correlations between the construct) indicates that the measure is discriminant.

Table 4: Inter- Correlation Matrix

\begin{tabular}{lccccc}
\hline & Attitudes & $\begin{array}{l}\text { Individual } \\
\text { Skills }\end{array}$ & $\begin{array}{l}\text { Intention } \\
\text { to use }\end{array}$ & $\begin{array}{l}\text { Perceived } \\
\text { Behavioural }\end{array}$ & $\begin{array}{l}\text { Subjective } \\
\text { Norms }\end{array}$ \\
\hline Attitudes & $\mathbf{0 . 7 6 3}$ & & & & \\
\hline Individual Skills & 0.754 & $\mathbf{0 . 8 1 0}$ & & & \\
\hline Intention to use & 0.723 & 0.597 & $\mathbf{0 . 7 8 8}$ & & \\
\hline $\begin{array}{l}\text { Perceived } \\
\text { Behavioural }\end{array}$ & 0.735 & 0.668 & 0.785 & $\mathbf{0 . 7 9 6}$ & \\
\hline $\begin{array}{l}\text { Subjective } \\
\text { Norms }\end{array}$ & 0.770 & 0.694 & 0.698 & 0.765 & $\mathbf{0 . 7 8 1}$ \\
\hline
\end{tabular}

Note: Bold values indicates the square root of AVE of each construct

According to Henseler et al., (2015), discriminant validity can be assessed through the multitrait and multimethod matrix, namely the Heterotrait-Monotrait Ratio (HTMT). Using HTMT criterion, if the values are greater than HTMT 0.85 indicate there was a problem with discriminant validity. As shown in Table 5 shows that the discriminant validity is validity is established because all of the value for HTMT were lower than most conservative value set by Henseler et al., (2015). 
Table 5: Heterotrait-monotrait Ratio (HTMT)

\begin{tabular}{llllll}
\hline \multicolumn{1}{c}{ ATT } & IS & ITU & PCB & SN \\
\hline ATT & & & & & \\
\hline IS & 0.796 & & & & \\
\hline ITU & 0.804 & 0.775 & & & \\
\hline PBC & 0.834 & 0.760 & 0.824 & & \\
\hline SN & 0.743 & 0.826 & 0.833 & 0.847 & \\
\hline
\end{tabular}

\section{Hypotheses Testing}

Before assessing the structural model, it is important to ensure that there are no collinearity issues in the structural model. To assess the structural model, Hair et al., (2017) suggested looking at the beta $(\beta)$ and the corresponding t-values via a bootstrapping procedure with a resample of 500. As asserted by Sullivan \& Feinn (2012), while a p-value can inform the reader whether an effect exists, the p-value will not reveal the size of the effect. In reporting and interpreting studies, both the substantive significance (effect size) and statistical significant ( $\mathrm{p}$-value) are essential result.

To validate the proposed hypotheses and the structural model, the path coefficient between two latent variables is assessed. Based on previous studies, the path coefficient value needs to be at least 0.1 to account for a specific impact within the model (Hair et al., 2011; Wetzels et al., 2009). From the analysis, supported hypotheses are significant at least at the level of 0.05, have expected sign directions (i.e., positive) and consist of a path coefficient value ( $\beta$ ).

The result reveal in Table 6 show that three hypotheses were supported (H2, H3, and H5) and another four hypothesis were found as not supported (H1, H4, H6 and H7). Individual Skills $(\beta=-0.006, \mathrm{t}=2.400: \mathrm{LL}=0.059, \mathrm{UL}=0.338, \mathrm{p}<0.008),(\beta=0.203, \mathrm{t}=21.718: \mathrm{LL}=$ $0.716, \mathrm{UL}=0.832, \mathrm{p}<0.001),(\beta=0.003, \mathrm{t}=15.638: \mathrm{LL}=0.630, \mathrm{UL}=0.781, \mathrm{p}<0.001)$ and $(\beta=-0.002, \mathrm{t}=1.641: \mathrm{LL}=0.590, \mathrm{UL}=0.765, \mathrm{p}<0.000)$. Attitude $(\beta=0.003, \mathrm{t}=$ 1.641: $\mathrm{LL}=0.010, \mathrm{UL}=0.369, \mathrm{p}<0.003)$. Subjective Norms $(\beta=-0.009, \mathrm{t}=0.433$ : $\mathrm{LL}=-$ $0.114, \mathrm{UL}=0.237, \mathrm{p}<0.333)$. Perceived Behavioural Control $(\beta=-0.005, \mathrm{t}=4.752: \mathrm{LL}=$ $0.301, \mathrm{UL}=0.621, \mathrm{p}<0.001)$.Some hypothesis show the value that it should be supported and unsupported, since the hypothesis generated was positive, and the finding found that it was negatively related, though it claimed as shown. Table 6.7 demonstrates the PLS estimation results.

Table 6: Hypotheses Testing

\begin{tabular}{llllllll}
\hline & Constructs & $\boldsymbol{\beta}$ & T-Value & P-Value & LL & UL & Result \\
\hline H1 & IS $\rightarrow$ ITU & -0.006 & 2.400 & 0.008 & 0.059 & 0.338 & Unsupported \\
\hline H2 & IS $\rightarrow$ ATT & 0.203 & 21.718 & 0.001 & 0.716 & 0.832 & Supported \\
\hline H3 & IS $\rightarrow$ SN & 0.003 & 15.638 & 0.001 & 0.630 & 0.781 & Supported \\
\hline H4 & IS $\rightarrow$ PBC & -0.002 & 13.003 & 0.001 & 0.590 & 0.756 & Unsupported \\
\hline H5 & ATT $\rightarrow$ ITU & 0.003 & 1.641 & 0.051 & 0.010 & 0.369 & Supported \\
\hline H6 & SN $\rightarrow$ ITU & -0.009 & 0.433 & 0.333 & -0.114 & 0.237 & Unsupported \\
\hline H7 & PBC $\rightarrow$ ITU & -0.005 & 4.752 & 0.001 & 0.301 & 0.621 & Unsupported \\
\hline
\end{tabular}

\section{Discussion and Conclusion}

The objective of this study is to analyse the intention of conducting Digital Education among school teachers in Malaysia. By adopting the TPB Framework, this study has revealed 
essential determinants that can influence the intention. This study has confirmed that the hypotheses for Individual skills on the attitudes and behaviours of the perceived behaviour, the attitude of the attitude used the norm of norms to be used, and the control of the perceived behaviour for the intention to use.

As a result, hypothesis $\mathrm{H} 1$ is not supported in the resulting hypothesis; there is a positive significance between individual skills and intention to use. After the hypothesis testing, we got a negative relationship between Individual skill and intention to use. Further, the result, $\mathrm{H} 2$, and $\mathrm{H} 3$ hypotheses are supported but $\mathrm{H} 4$ are not supported. This decision is in line with previous studies that examine Attitudes with Individual Skills (Kruglanski et al., 2015). Similarly, Petty and Wegener (1998) affirmed that "attitudes (are) because of the fundamental role that individual' attitudes. Garrison et al., (2016)this study is in line with the decision between Subjective Norms with Individual Skills, and the Subjective norm is the social pressure exerted on an individual for performing or not performing a specific behaviour (Fishein \& Ajzen, 1975; Fishbein \& Ajzen, 2010).Even in past studies such as .an individual's belief about the "presence or absence of requisite resources and opportunities" (Yi et al., 2017) and Individual Skills and theorizing perceived behavioural control as a determinant of intention as well as behaviour (Ajzen, 1985) states Individual Skills have a positive relationship with the $\mathrm{PBC}$ but based on this study we got a negative relationship between Individual skill and PBC.

Next, the hypothesis H5 is supported, but H6 and H7 are not supported. This decision is in line with previous studies that examine Attitudes with Intention to use (Vigoda, 2000) show that attitudes affect the behavioural intentions. Even in past studies such as have state the subjective norms are proposed to influence behaviour through their impact upon intentions their impact upon intentions this study is in line with the decision between Subjective Norms with Intention and Perceived Behavioural Control will add to the prediction of behaviour over and above the effect of behavioural intention (Sutton, 1998)but based on this study we got a negative relationship between Subjective Norms with Intention to use and Perceived Behavioural Control with Intention to use.

The study has the limitation that gives the impetus for further research in the field of investigation. First, our analysis is cross-sectional and measures the teachers' intention in using digital education which may be less common than longitudinal studies, and this study predicts the user's intention. Hence, future research can be done on the behaviour of real consumer customers and further increase the number of respondents to obtain more significant data. Also, this study should involve teachers in government and private schools comprising primary and secondary school teachers to learn more about the provision of teachers in Malaysia on digital education now. This study has contributed to research by explaining the ongoing features of knowledge sharing and the determinants of continuous intentions in the context of digital education and intention to use. Theoretical contributions are presented below: First, this article contributes to providing a better understanding of ongoing knowledge sharing and identifying the theoretical foundations that describe this current behaviour. Secondly, this study uses the theory of Planned Behaviour, to explain more about what determines Intention to use in the community of teachers towards digital education. This study follows strictly as the presumption of this theoretical model by using only the constant associated factors as a determinant.

In the context of management, this study provides information on the Intention of teachers in using digital education to MOE. Based on the empirical results of this study, individual skills 
acquired for a teacher do not affect the intention to use digital education among school teachers. This demonstrates the ability of teachers on electronic items and digital literacy that needs to be applied in schools is still in good stead. This is because teacher's still need sufficient training to use and apply this digital education better. This data can help MOE realise the new standardisation of Digital Education among teachers. The findings of this study will help the Malaysian Education Ministry to devise strategies to support and motivate academicians to use the Internet more in their work to prepare for changes in school teaching and learning processes to become e-schools.

\section{References}

Abas, Z. W. (1995, March). Attitudes towards using computers among Malaysian teacher education students. In IFIP World Conference on Computers in Education (pp. 153162). Springer, Boston, MA.

Abdullah, M., \& Osman, K. (2010). 21 st century inventive thinking skills among primary students.

Ajzen, I. (1988). Attitudes, Personality, and Behavior. Chicago: IL: Dorsey.

Ajzen, I. (1985). Behavioral Interventions Based on the Theory of Planned Behavior.

Ajzen, I., (2006). Constructing a TpB Questionnaire: Conceptual and Methodological.

Ajzen, I. (1991). The theory of planned behavior. Organizational Behavior and Human Decision Processes.

Ajzen, I., \& Fishbein, M. (1980). Understanding attitudes and predicting social behavior.

Armitage, C. J., \& Conner, M. (2001). Efficacy Of The Theory Of Planned Behavior: AmetaAnalytic Review

Arsyad, A. (2011). Media dan Sumber Pengajaran, 23-35.

Azizi Yahaya \& Rosnani Mohd Nor. (2015). Keberkesanan Pengajaran Dan Pembelajaran Di Kalangan Guru Matapelajaran Teknikal.

Bali, N. J. (2014). Hubungan Antara Pengharapan, Sikap Terhadap Perkhidmatan Kaunseling Dan Niat Untuk Mendapatkan Perkhidmatan Kaunseling Dalam Kalangan Pelajar Berisiko.

Bidin, Z., Shamsudin, F. M., Sharif, Z., \& Hashim, M. F. A. M. (2011, October). Determinants of students' internet usage for academic purposes. In World Business and Social Science Research Conference, October.

Brouwer, S., Krol, B., Reneman, M. F., Bultman, U., Franche, R. L., Klink, J. J. L. van der, \& Groothoff, J. W. (2009). Behavioral Determinants as Predictors of Return to Work After Long-Term Sickness Absence: An Application of the Theory of Planned Behavior.

Buhmann, A., Bronn, P. S., Buhmann, A., \& Bronn, P. S. (2018). measure and evaluate communication outcomes Applying Ajzen's theory of planned behavior to predict practitioners ' intentions to measure and evaluate communication outcomes.

Buntat, Y. (2010). Aplikasi 'E-Learning 'Dalam Pengajaran \& Pembelajaran Di SekolahSekolah Malaysia: Isu Dan Cadangan Perlaksanaannya. Fakulti Pendidikan Universiti Teknologi Malaysia.

Chin, W. W. (1998). The partial least squares approach to structural equation modeling. Modern methods for business research, 295(2), 295-336.

Chuchinprakarn, S. (2005). Application of the Theory of Reasoned Action to On-line Shopping.

Close, M. A., Lytle, L. A., Chen, D.-G., \& Anthony J. Viera. (2015). Nutrition \& Food Science.

Cohen, J. (1988). Statistical power analysis for the behavioral sciences (2nd ed.). Hillsdale, NJ: Erlbaum. 
Compeau, D. R., \& Higgins, C. A. (2018). Computer Self-Efficacy: Development of a Measure and Initial Test.

Deasy \& Firniawati, (2014). Membangun Customer Relationship Management (Crm) Berbasis Website Pada Testtube Clothing and Digital Printing, 1-9.

Fanning, F. H., \& Ricks, J. M. (2017). Attitudes, social norms, and perceived behavioral control factors influencing participation in a cooking skills program in rural Central Appalachia.

Fishbein, M., \& Ajzen, I. (2010). Predicting and changing behavior: The reasoned action approach. New York: Taylor \& Francis.

Fornell, C., \& Larcker, D. F. (1981). Structural Equation Models with Unobservable variables and measurement error: Algebra and statistics.

Garrison, G., Jr, C. M. R., Kim, S. H., Garrison, G., Rebman, C. M., \& Hyun, S. (2016). An Identification of Factors Motivating Individuals .

Gefen, D., Rigdon, E.E. and Straub, D. (2011).Editor's Comments: An Update and Extension to SEM Guidelines for Administrative and Social Science Research.

Gilakjani, A. P., Lai-Mei, L., \& Ismail, H. N. (2013). Teachers' use of technology and constructivism. International Journal of Modern Education and Computer Science, $5(4), 49$.

Green, S. B. (1991). How many subject does it take to do a regression analysis?

Hair, J.F., Ringle, C.M. and Sarstedt, M. (2011) 'PLS-SEM: indeed a silver bullet', The Journal of Marketing Theory and Practice.

Hair, J.F., Sarstedt, M., Ringle, C.M., Thiele, K.O. and Gudergan, S.P. (2016) 'Estimation issues with PLS and CBSEM

Hair Jr, J. F., Sarstedt, M., Ringle, C. M., \& Gudergan, S. P. (2017). Advanced issues in partial least squares structural equation modeling. Sage Publications.

Ham, M., Jeger, M., \& Ivković, A. F. (2016). The role of subjective norms in forming the intention to purchase green food.

Hartwick, J., \& Barki, H. 1994, „Explaining the role of user participation in information

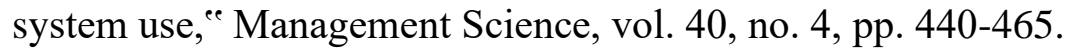

Hebert, D. G. (2007). Bruno Nettl's the study of ethnomusicology: Thirty-one issues and concepts: An essay review. International Journal of Education and the Arts, 8.

Henseler, J., Ringle, C. M., \& Sarstedt, M. (2015). A new criterion for assessing discriminant validity in variance-based structural equation modeling.

Holwerda, J. (2018). The Relationship between Entrepreneurial Skills and Intentions.

Hunter, W. and deLeeuw, G. (1988, June). Computers in teacher education. Paper presented to the Association for Media and Technology, Halifax

Igbaria, M., Parasuraman, S., \& Baroudi, J. (2015). A Motivational Model of Microcomputer Usage.

Jamaluddin, C. \&. (2010). Sikap Guru Bahasa Melayu terhadap Penggunaan Teknologi Maklumat dan Komunikasi ( ICT ) dalam Pengajaran di Sekolah-sekolah Rendah di Bintulu , Sarawak, 35(1), 59-65.

Kabir, M. A., Saidin, S. Z., \& Ahmi, A. (2017). A conceptual framework on the influence of perceived usefulness, perceived ease use and computer self- efficacy on the intention to use electronic collection system in nigerian federal hospitals, 7(3), 259-266.

Kam, K., So, F., Oh, H., \& Min, S. (2018). Motivations and constraints of Airbnb consumers : Findings from a mixed-methods approach.

Koohang, A.A. (1989) A study of attitudes toward computers: Anxiety, confidence, liking and perception of usefulness. Journal of Research on Computing in Education, 22 (2) pp. 137-50. 
Kruglanski, A. W., Chernikova, M., Milyavsky, M., Baldner, C., \& Pierro, A. (2015). The Rocky Road From Attitudes to Behaviors: Charting the Goal Systemic Course of Actions.

Lubis, M. A. (2017). ASEAN Comparative Education Research Journal on Islam and Civilization (ACER-J). Tahap pengetahuan dan kesediaan guru-guru pendidikan islam sekolah menengah di selangor terhadap penggunaan multimedia dalam pengajaran pendidikan islam.

NICD. National Institute of Career Development (2006). Findings for Children up to Age 41/2 Years.

Mathieson, K. 1991, „Predicting user intentions: Comparing the technology acceptance model with the theory of planned behavior, "Information System Research, vol. 2, no. 3, pp.173-191.

Mohamed, M. A. (2011). Penggunaan Sistem E-Learning Di Fakulti Pendidikan Universiti Teknologi Malaysia (Doctoral dissertation, Universiti Teknologi Malaysia).

Moore, G., \& Benbasat, I. 1993, „An empirical examination of a model of the factors affecting utilization of information technology by end-users, " Working paper, Faculty of Commerce, University of British Columbia, Vancouver.

Nurmi, J., Kiuru, N., Lerkkanen, M., Niemi, P., \& Poikkeus, A. (2013). Teachers adapt their instruction in reading according to individual childrens literacy skills . Learning and Individual Differences,

Petty, R. E., and Wegener, D. T. (1998). Attitude change: Multiple roles for persuasion variables. In D. T.

Rahman et. al. (2016). Knowledge sharing behaviors among non academic staff of higher learning institutions: Attitude, subjective norms and behavioral intention embedded model.

Reni, F., \& Anggraini, R. (2016). The Role of Perceived Behavioral Control and Subjective Norms to Internal Auditors ' Intention in Conveying Unethical Behavior: A Case Study in Indonesia.

Rhodes, R. E., Jones, L. W., \& Courneya, K. S. (2013). Research Quarterly for Exercise and Sport.

Ringle, C.M., Wende, S. and Becker, J-M. (2015) Smartpls 3. Bonningstedt: SmartPLS [online] http://www.smartpls.com

Samian, S., \& Awang, A. (2017). Pendidikan Sebagai Komponen Kualiti Hidup Masyarakat Pinggir Bandar (Education As Quality Components Of Life In The Suburban Community). Asian Journal Of Environment, History And Heritage, 1(1).

Saric, M. (2015). Marjeta Saric Teachers' emotions : a research review from a psychological perspective, 10-26.

Shanmugan \& Balakrishnan. (2018). Kerangka Panduan Efektif Pengajaran Dan Pemudahcaraan (PdPc) Sains Menggunakan Information Communication Technology (ICT) di Sekolah Jenis Kebangsaan Tamil (SJK) (TAML), 1, 25-35.

Smith, A. L. P. W. E. L. K. (2018). Toward an Integrative Framework for Studying Human Evaluation: Attitudes towards Objects and Attributes.

Soares, O., Rui, C., \& Goncalves, A. (2017). Policing: An International Journal of Police Strategies \& Management Article information

Stevens, D.J. (1980) How educators perceive computers in the classroom. AEDS Journal, 13, pp. 221-32.

Sullivan, G. M., \& Feinn, R. (2012). Using effect size-or why the P value is not enough. Journal of graduate medical education, 4(3), 279-282.

Sumida, K., Fujimoto, J., \& Sakata, M. (2014). Differentiating attitudes: team loyalty and attitude towards spectating behaviour. Sport, Business and Management. 
Sutton, S. (1998). Predicting and Explaining Intentions and Behavior: How Well Are We Doing?

Urbach, N., \& Ahlemann, F. (2010). Structural Equation Modeling in Information Systems Research Using Partial Least Squares Structural Equation Modeling in Information Systems Research Using Partial Least Squares, 11(2), 5-40.

Vigoda, E. (2000). Organizational Politics, Job Attitudes, and Work Outcomes : Exploration and Implications for the Public Sector.

Wetzels, Odekerken-Schroder, \& van Oppen. (2009). Using PLS Path Modeling for Assessing Hierarchical Construct Models: Guidelines and Empirical Illustration

Yahaya, A., Hashim, S., \& Mohamed, F. (2006). Tahap Penguasaan Kemahiran Manipulatif di Kalangan Guru Pelatih Kimia Universiti Teknologi Malysia.

Yarmen, M., Sumaedi, S., Bakti, I. G. M. Y., Rakhmawati, T., Astrini, N. J., \& Widianti, T. (2016). Investigating patient loyalty.

Yi, M. Y., Jackson, J. D., Park, J. S., \& Probst, J. C. (2017). personal innovativeness and user acceptance of technology Understanding information technology acceptance by individual professionals : Toward an integrative view, (June 2013). 